not differ significantly between those patients who had taken nonsteroidal anti-inflammatory drugs ( 20 out of $22 ; 91 \%$ ) and those who had not ( 33 out of $48 ; 69 \%$ ). The relative frequency of consumption of individual non-steroidal anti-inflammatory drugs did not differ between the patients with stricture and the controls (table), and ibuprofen, indomethacin, and aspirin were the drugs most often used by both groups.

\section{Discussion}

We found an association between prior consumption of non-steroidal anti-inflammatory drugs and the development of benign oesophageal stricture. Before dysphagia occurred most of our patients had had symptoms of gastro-oesophageal reflux, and almost all had evidence of reflux at the time the stricture was diagnosed. This suggests that such drugs may aggravate reflux oesophagitis and so increase the risk of formation of stricture.

Swallowed tablets may remain in the oesophagus for considerable periods; Evans and Roberts ${ }^{5}$ found that in 57 out of 98 patients without organic obstruction barium sulphate tablets remained in the oesophagus for five minutes or longer during recumbency. Oesophageal emptying is slow in the elderly, and clearing is impaired in the presence of gastrooesophageal reflux with resulting disorder of motility. For these reasons passage of the non-steroidal anti-inflammatory drugs might have been slow even before stricture developed, resulting in prolonged exposure of the oesophageal mucosa to their irritant action.

Prostaglandins are believed to have a cytoprotective action on the gastric mucosa, ${ }^{6}$ and non-steroidal anti-inflammatory $\square$ drugs may exert their ulcerogenic effect by reducing generation of mucosal prostaglandins. A similar action in the oesophagus $\frac{\widehat{\Phi}}{2}$ might contribute to mucosal damage and aggravate reflux oesophagitis.

The proportion of patients suffering from rheumatoid disease $\frac{\widehat{\Omega}}{\overline{7}}$ did not differ significantly between the patients with peptic $\supset$ stricture and the controls, which suggests that rheumatoid $\Phi$ disease in itself does not predispose to the formation of stricture. $m$

These findings indicate that non-steroidal anti-inflammatory drugs should be prescribed with caution in the presence of $\vec{\equiv}$ symptomatic gastro-oesophageal reflux; if they are used endos- $\stackrel{\oplus}{\stackrel{9}{9}}$ copic monitoring for oesophageal damage would seem advisable. 을

\section{References}

${ }^{1}$ Collins FJ, Matthews HR, Baker SE, Strakova JM. Drug-induced $\vec{\circ}$ oesophageal injury. $\mathrm{Br} \mathrm{Med} \mathcal{F} 1979$;i:1673-6.

2 Agdal N. Drug induced oesophageal damage. Review and report of a $\vec{\omega}$ fatal case of indomethacin induced ulceration. Ugeskr Laeger 1979;141: 3019-21.

${ }^{3}$ Fellows IW, Ogilvie AL, Atkinson M. Oesophageal stricture associated with emepronium bromide therapy. Postgrad Med f 1982;75:43-4

4 Carlborg B, Kumlien A, Olsson H. Oesophageal strictures induced by oral drug therapy. Lakartidningen 1978;75:4609-11.

5 Evans KT, Roberts GM. Where do all the tablets go ? Lancet 1976;ii: W 1237-9. ${ }^{6}$ Robert A, Nezamis JE, Lancaster C, Hanchar AJ. Cytoprotection by $\vec{\circ}$
prostaglandins in rats. Gastroenterology $1979 ; 77: 433-43$.

(Accepted 25 May 1982)

\title{
Pregnancy after surgical correction of tetralogy of Fallot
}

\author{
H SINGH，P J BOLTON，C M OAKLEY
}

\begin{abstract}
Forty pregnancies have been documented in 27 patients with surgically corrected tetralogy of Fallot. Infertility was uncommon and there were no premature births and few abortions or small-for-dates babies; this suggests that surgery that corrects cyanosis improves the outcome of pregnancy by correcting the fetal environment. Pregnancy was well tolerated and there were no serious cardiac complications. Thirty of the 31 infants examined were normal, the one abnormal infant having pulmonary atresia.
\end{abstract}

A patient with no major residual defects after surgery for tetralogy of Fallot may be reassured that pregnancy will be well tolerated and that delivery may be managed in the normal manner.

\section{Introduction}

"Total" or radical surgical correction of tetralogy of Fallot has become standard practice, and of those patients surviving radical surgery about $95 \%$ are alive five to 10 years later. ${ }^{1-3}$ About half the deaths occurring after the perioperative period are in the first postoperative year and are caused by heart failure resulting from residual abnormalities. These include ventricular septal defects, pulmonary hypertension, and abnormalities of conduction or rhythm. Survivors of surgery show an improvement in effort tolerance and loss of cyanosis. ${ }^{24}$

Uncorrected cyanotic heart disease carries a high risk in $D$ pregnancy for both mother and fetus: a review of 57 pregnancies in women with uncorrected tetralogy of Fallot showed a fetal N mortality of $22 \%$ and a maternal mortality of $7 \% .^{5}$ The high $\underset{\mathrm{N}}{ }$ fetal mortality was caused by poor fetal growth, leading to a 0 high incidence of abortion, prematurity, and small-for-dates babies. Pregnancy in patients with surgically corrected tetralogy of Fallot is increasing, but no large, detailed series of such $\stackrel{?}{?}$ pregnancies has been reported.

\section{London W12 0HS}

H SINGH, MRCP, registrar in cardiology (present appointment: lecturer in cardiology, University Hospital of Wales, Heath Park, Cardiff)

P J BOLTON, MRCOG, senior registrar in obstetrics and gynaecology (present appointment: consultant in obstetrics and gynaecology, Harold Wood Hospital, Essex)

C M OAKLEY, MD, FRCP, consultant cardiologist

\section{Patients and methods}

All women who had had a total correction of tetralogy of Fallot at Hammersmith Hospital during the period 1958-74 and who were o now aged 16 or over were considered for the study. Of the original group of 100 patients, 23 had returned abroad. In these and a further

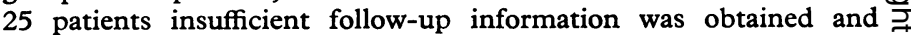
they were therefore not included in the study. 
A questionnaire asking for details of infertility, pregnancies, and miscarriages was sent to the remaining 52 patients. Full obstetric and cardiological details of each pregnancy were requested from the obstetric department supervising each pregnancy. The case records at the Hammersmith Hospital were consulted to provide details of the type of operation-that is, whether the closure of the ventricular septal defect had been by direct suture or by a patch, and whether a right ventricular outflow patch had been required. Any previous palliative or shunt procedures were noted. The success of the operation was assessed by recording residual defects-that is, persistent ventricular septal defects, right ventricular outflow tract obstruction, pulmonary regurgitation, electrocardiographic abnormalities, and documented arrhythmias.

\section{Results}

Twenty-five patients had had no pregnancies, but only one complained of infertility. A total of six miscarriages had occurred in two patients, both of whom had achieved at least one successful pregnancy. Two patients had had termination of pregnancy for reasons other than their cardiac disease. There were a total of 40 successful pregnancies in 27 patients.

\section{CARDIAC DETAILS OF PREgNANCY}

There were no serious cardiac complications in the 31 pregnancies about which we obtained detailed information. No patient developed overt cardiac failure and none required prolonged admission to hospital for any medical reason. Nine patients developed mild ankle oedema but no specific treatment was required. One patient received thiazide diuretics for mild dyspnoea but there were no other signs of cardiac failure. There were no reports of syncopal attacks or chest pain. Extrasystoles were noted in one patient during the pregnancy and puerperium but such ectopics had been recorded even before pregnancy.

\section{OBSTETRIC DETAILS}

The only obstetric antenatal complications were transient mild hypertension (diastolic blood pressure above $90 \mathrm{~mm} \mathrm{Hg}$ ) in six patients and mild oedema in nine.

The gestational age ranged from 35 to 42 weeks (mean 39). Labour was induced in five patients, cardiac disease being given as the indication in only one. Of the 31 deliveries about which we have detailed information 15 were spontaneous vaginal deliveries. There were 14 forceps deliveries, half of which were for cardiac disease. Two patients required caesarean section, one for cephalopelvic disproportion and the other for prolapse of the cord. The mean duration of the first stage was 6.8 hours (range 1.5 to 17) and of the second stage 35 minutes (range 5 to 130). Analgesia was achieved by epidural block in seven patients, narcotics in 11, and nitrous oxide with oxygen in three. Oral antibiotic prophylaxis against endocarditis was given in 24 of 28 patients where details were available. No puerperal problems were encountered.

Of the 31 infants (18 boys, 13 girls) examined in this study, 30 were essentially normal (two had physiological jaundice and one a mild intrauterine infection). One infant has pulmonary atresia and is under cardiological surveillance. The mean birth weight of the 18 boys was $3.0 \mathrm{~kg}$ (range 2.37 to $3.82 \mathrm{~kg}$ ), whereas in the 13 girls the mean weight was $2.90 \mathrm{~kg}$ (range 2.06 to $3.54 \mathrm{~kg}$ ): three of the boys $(17 \%)$ and three of the girls $(23 \%)$ were below the 10 th centile for weight.

\section{CARDIAC SURGERY AND RESIDUAL DEFECTS}

The 27 patients who had been pregnant (group 1) were compared with the 25 who had not (group 2). The table lists the features that were evaluated and gives the numbers and percentage of patients in each group in whom there was a positive finding for any given factor.

Whether or not a patch was necessary, either to close the ventricular septal defect or to enlarge the right ventricular outflow tract, is an indirect indication of the complexity of the congenital defect. Previous surgery in all cases consisted of either a Blalock-Taussig shunt or a Brock precedure. Two of the women with residual ventricular septal defects required a second operation after successful pregnancies. Obstruction of the right ventricular outflow tract or pulmonary regurgitation, or both, were fairly frequent residual findings but in all cases were of little haemodynamic importance. The documented arrhythmias consisted of isolated ventricular extrasystoles in six patients and supraventricular ectopics in one.

Analysis of cardiac surgery and residual defects in patients who had successful pregnancies (group 1) and in those who had no children (group 2)

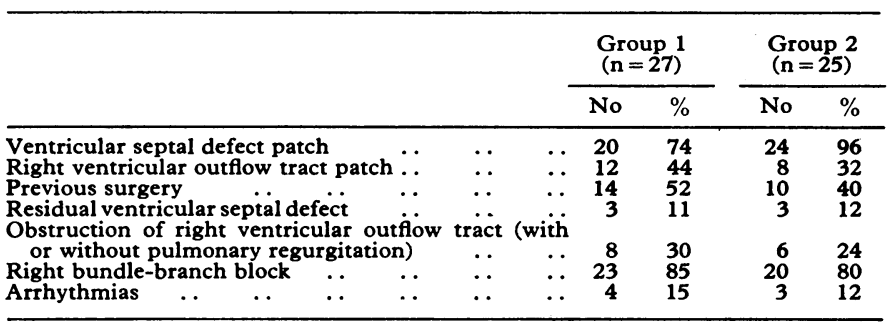

\section{Discussion}

Surgical repair of tetralogy of Fallot has a low perioperative mortality and survivors are usually much improved symptomatically. A small incidence of sudden death has been reported in the years after repair, the two most likely mechanisms being the development of defects in conduction and ventricular tachyarrhythmias. Specific cardiovascular changes accompanying pregnancy include a reduction in systemic vascular resistance and a diminution in venous return from supine hypotension. These factors, together with anaesthesia and blood loss, may represent a greater than normal risk in patients with tetralogy of Fallot, but to date no large series has assessed this risk. In our series there were no serious cardiac complications during pregnancy or at delivery, suggesting that survivors of surgery are able to cope adequately with the demands of pregnancy.

It might be argued that women having successful pregnancies represent those with the best results from surgery. We therefore compared these patients with a group of mostly unmarried women who had not had children. As the table shows there was no significant difference between the two groups in terms of residual defects. We therefore concluded that our group of patients who had had children represented a cross-section of survivors.

The incidence of miscarriage was no higher than one might expect in the general population, and infertility occurred in only one patient. Surgical repair may be said to improve fertility as it is recognised that patients with cyanotic heart disease are subfertile.

Of the 31 pregnancies about which we have detailed information, 30 resulted in normal infants, the one abnormal infant having pulmonary atresia. Though the incidence of congenital heart disease is greater than normal in the offspring of patients with congenital heart disease, the numbers in our study are too small for any conclusions to be drawn on this point.

The obstetric details suggest that pregnancy in corrected tetralogy of Fallot is comparable with that in the normal population. The incidence of forceps deliveries seems high, probably reflecting caution in obstetricians not wishing to prolong the stress associated with the second stage of labour.

We suggest that a patient who has had a surgical correction of tetralogy of Fallot should be examined early in pregnancy. Provided that there are no major residual defects she may be reassured that the corrected cardiac lesion does not expose her to any additional risk during the pregnancy. The pregnancy may be managed in the normal manner with no special precautions and it is highly likely that pregnancy and delivery will be uncomplicated. 


\section{References}

${ }^{1}$ Kirklin JW, Wallace RB, McGoon DC, et al. Early and late results after intracardiac repair of tetralogy of Fallot. Five years' review of 337 patients. Ann Surg $1965 ; 165 \cdot 578-89$.

${ }^{2}$ Gersony WM, Battany S, Bowman FO Jr, et al. Late follow-up of patients evaluated haemodynamically after total correction of tetralogy of Fallot. f Thorac Cardiovasc Surg 1973;66:209-13.

${ }^{3}$ Clayman JA, Ankeney JL, Liebman J. Results of complete repair of tetralogy of Fallot in 156 consecutive patients. Am F Surg 1975;130: 601-5.
${ }^{4}$ Hallidie-Smith KA, Dulake M, Wong M, Oakley CM, Goodwin JF. Ventricular structure and function after radical correction of the tetralogy of Fallot. Br Heart $\mathcal{F} 1967 ; 29: 533-47$.

5 Meyer EC, Tulsky AS, Sigmann P, Silber EN. Pregnancy in the presence of tetralogy of Fallot. Am $\mathcal{F}$ Cardiol $1964 ; 14: 874-9$.

6 James FW, Kaplan S, Chou TC. Unexpected cardiac arrest in patients after surgical correction of tetralogy of Fallot. Circulation 1975;52: 691-5.

(Accepted 4 fune 1982)

\title{
Changes in serum amylase and its isoenzymes after whole body irradiation
}

\author{
A BARRETT, A JACOBS, J KOHN, J RAYMOND, R L POWLES
}

\begin{abstract}
A study was carried out to assess the effect of total body irradiation on pancreatic and parotid isoenzymes of amylase in patients about to undergo bone-marrow transplantation who had received high-dose cyclophosphamide. Twelve patients were studied, enzyme activity being measured before and at various times after total body irradiation. Serum total amylase activity rose rapidly within 12 hours of irradiation to a maximum at 36 hours, returning to normal by six days; most of the increase was derived from salivary damage, with a much smaller pancreatic component.

These results confirm that radiation produces acute changes in amylase activity, which may be of use in assessing radiation-induced damage.
\end{abstract}

\section{Introduction}

The preconditioning regimen for patients undergoing bonemarrow transplantation for acute leukaemia includes high-dose cyclophosphamide $\left(3 \mathrm{~g} / \mathrm{m}^{2} \times 2\right)$ followed by total body irradiation to a dose of about $10 \mathrm{~Gy}$ (1000 rad). A rise in serum amylase activity was noted in these patients, and acute parotitis occurred. We therefore undertook a study to determine the effect of total body irradiation on pancreatic and parotid isoenzymes of amylase.

\section{Patients, methods, and results}

Serum amylase activity was measured in 10 consecutive unselected patients before total body irradiation and daily until it returned to normal using the Phadebas method. ${ }^{1}$ Serum amylase and pancreatic and salivary isoenzyme activities were then measured in a further 12 patients before total body irradiation and at varying times after

Institute of Cancer Research and The Royal Marsden Hospital, Sutton, Surrey

A BARRETT, MB, FRCR, senior lecturer and honorary consultant in radiotherapy

A JACOBS, BSC, MRCP, registrar in haematology (present appointment: fellow, Division of Haematology-Oncology, University of California, Los Angeles, California 90024, USA)

J KOHN, FRCPATH, DCP, consultant clinical pathologist

J RAYMOND, BSC, medical laboratory scientific officer

R L POWLES, MD, FRCP, physician in charge, leukaemia unit treatment using a quantitative inhibition technique, a diagnostic isoamylase test (Pharmacia), ${ }^{2}$ and electrophoretic separation cellulose acetate as reported by Davis. ${ }^{3}$ Control values were obtained in 16

Amylase activity before (pre) and after total body irradiation*

\begin{tabular}{|c|c|c|c|c|}
\hline $\begin{array}{l}\text { Case } \\
\text { No }\end{array}$ & $\begin{array}{c}\text { Time of } \\
\text { measurement } \\
\text { (hours) }\end{array}$ & $\begin{array}{c}\text { Total } \\
\text { amylase } \\
(\mathrm{U}+/ 1)\end{array}$ & $\begin{array}{c}\text { Pancreatic } \\
\text { isoenzyme } \\
(\mathrm{U} / 1)\end{array}$ & $\begin{array}{c}\text { Salivary } \\
\text { isoenzyme } \\
(\mathrm{U} / \mathrm{l})\end{array}$ \\
\hline \multirow{5}{*}{1} & $\begin{array}{l}\text { Pre } \\
24\end{array}$ & $\begin{array}{r}90 \\
2490\end{array}$ & $\begin{array}{r}66 \\
594\end{array}$ & $\begin{array}{r}84 \\
1896\end{array}$ \\
\hline & $\begin{array}{l}48 \\
60\end{array}$ & $\begin{array}{r}1296 \\
918\end{array}$ & $\begin{array}{l}360 \\
270\end{array}$ & 936 \\
\hline & $\begin{array}{l}60 \\
72\end{array}$ & $\begin{array}{l}918 \\
216\end{array}$ & $\begin{array}{r}770 \\
54\end{array}$ & $\begin{array}{l}648 \\
162\end{array}$ \\
\hline & Pre & 78 & 48 & 30 \\
\hline & 12 & 720 & 420 & 300 \\
\hline \multirow[t]{3}{*}{2} & 24 & 1600 & 732 & 870 \\
\hline & $\begin{array}{l}48 \\
72\end{array}$ & $\begin{array}{l}290 \\
432\end{array}$ & $\begin{array}{l}486 \\
180\end{array}$ & $\begin{array}{r}1800 \\
252\end{array}$ \\
\hline & Pre & 36 & 24 & 12 \\
\hline \multirow[t]{2}{*}{3} & 24 & 520 & 180 & 342 \\
\hline & 48 & 660 & 144 & 420 \\
\hline \multirow{4}{*}{4} & Pre & 66 & 42 & 24 \\
\hline & 24 & $\begin{array}{r}2400 \\
2600\end{array}$ & $\begin{array}{l}480 \\
102\end{array}$ & 1920 \\
\hline & $\begin{array}{l}48 \\
72\end{array}$ & $\begin{array}{r}2600 \\
420\end{array}$ & $\begin{array}{l}192 \\
150\end{array}$ & 1440 \\
\hline & Pre & $\begin{array}{l}420 \\
290\end{array}$ & $\begin{array}{r}150 \\
60\end{array}$ & 270 \\
\hline \multirow{5}{*}{5} & 12 & 4800 & $\begin{array}{r}60 \\
1100\end{array}$ & $\begin{array}{r}204 \\
3420\end{array}$ \\
\hline & 36 & 2100 & 414 & 1550 \\
\hline & 48 & 1700 & 470 & 1170 \\
\hline & $\begin{array}{l}60 \\
72\end{array}$ & $\begin{array}{r}1000 \\
800\end{array}$ & $\begin{array}{l}288 \\
48\end{array}$ & $\begin{array}{l}740 \\
792\end{array}$ \\
\hline & Pre & 72 & 36 & $\begin{array}{r}92 \\
36\end{array}$ \\
\hline \multirow{3}{*}{6} & $\begin{array}{l}244 \\
36\end{array}$ & $\begin{array}{l}1530 \\
4000\end{array}$ & $\begin{array}{r}1044 \\
72\end{array}$ & $\begin{array}{r}396 \\
3888\end{array}$ \\
\hline & $\begin{array}{l}30 \\
48\end{array}$ & 4460 & 324 & $\begin{array}{r}5888 \\
4140\end{array}$ \\
\hline & $\begin{array}{l}60 \\
72\end{array}$ & $\begin{array}{l}720 \\
468\end{array}$ & $\begin{array}{l}306 \\
126\end{array}$ & $\begin{array}{l}414 \\
342\end{array}$ \\
\hline \multirow{3}{*}{7} & 12 & 2340 & 522 & 1818 \\
\hline & $\begin{array}{l}244 \\
48\end{array}$ & 2160 & 522 & 1638 \\
\hline & $\begin{array}{l}48 \\
72\end{array}$ & $\begin{array}{l}864 \\
360\end{array}$ & $\begin{array}{r}204 \\
66\end{array}$ & $\begin{array}{l}660 \\
294\end{array}$ \\
\hline \multirow{3}{*}{8} & Pre & 132 & 6 & 126 \\
\hline & 12 & 2340 & 522 & 1818 \\
\hline & $\begin{array}{l}36 \\
60\end{array}$ & $\begin{array}{r}540 \\
78\end{array}$ & $\begin{array}{r}144 \\
12\end{array}$ & $\begin{array}{r}396 \\
66\end{array}$ \\
\hline \multirow{3}{*}{9} & Pre & 132 & 6 & $\begin{array}{r}00 \\
126\end{array}$ \\
\hline & 12 & 2160 & 504 & 1656 \\
\hline & $\begin{array}{l}30 \\
60\end{array}$ & 288 & $\begin{array}{r}48 \\
48\end{array}$ & $\begin{array}{l}828 \\
240\end{array}$ \\
\hline \multirow{4}{*}{10} & Pre & 138 & 42 & 96 \\
\hline & 12 & 810 & 180 & 630 \\
\hline & & 195 & 12 & 183 \\
\hline & $\begin{array}{r}60 \\
108\end{array}$ & $\begin{array}{r}180 \\
90\end{array}$ & $\begin{array}{l}66 \\
36\end{array}$ & $\begin{array}{r}114 \\
54\end{array}$ \\
\hline \multirow{3}{*}{11} & 12 & 9000 & 1200 & 6024 \\
\hline & 24 & $\begin{array}{r}5600 \\
3\end{array}$ & 1000 & 4500 \\
\hline & $\begin{array}{l}48 \\
72\end{array}$ & $\begin{array}{l}3000 \\
1100\end{array}$ & $\begin{array}{r}210 \\
78\end{array}$ & $\begin{array}{r}3000 \\
900\end{array}$ \\
\hline \multirow{3}{*}{12} & Pre & 140 & 120 & 40 \\
\hline & 12 & 2300 & 620 & 1920 \\
\hline & $\begin{array}{l}36 \\
60\end{array}$ & $\begin{array}{l}900 \\
340\end{array}$ & $\begin{array}{l}120 \\
120\end{array}$ & $\begin{array}{r}800 \\
40\end{array}$ \\
\hline
\end{tabular}

*Control values-normal subjects $(\mathrm{n}=16)$ : total amylase $170 \mathrm{U} / 1$, pancreatic isoenzyme $87 \mathrm{U} / 1$, salivary isoenzyme $83 \mathrm{U} / 1$; leukaemic patients $(\mathrm{n}=9)$ : total amylase $178 \mathrm{U} / 1$, pancreatic isoenzyme $80 \mathrm{U} /$, salivary isoenzyme $98 \mathrm{U} / \mathrm{l}$ tOne unit of amylase is the amount of enzyme catalysing the hydrolysis of $1 \mu \mathrm{mol}$
of substrate (glucosidic linkage)/minute at $37^{\circ} \mathrm{C}$ and is equivalent to $60 \mu \mathrm{katals}$. 